PRIFYSGOL

glyndŵn

Glyndŵr University

Glyndŵr University Research Online

Theology

Theology

$1-1-2008$

\title{
Sunderland's Legacy in New Denominations
}

William K. Kay

GlyndwrUniversity, w.kay@glyndwr.ac.uk

Follow this and additional works at: http://epubs.glyndwr.ac.uk/theo

Part of the Religious Thought, Theology and Philosophy of Religion Commons

Presented at Pentecost at Sunderland: centenary conference on Pentecostal origins in Britain St

John's College, Durham 19-21 September 2007. This is an electronic version of an article published in the Journal of the European Pentecostal Theological Association in 2008. The journal website is available at http://www.eptaonline.com/

\section{Recommended Citation}

Kay, W. K. (2008) 'Sunderland's Legacy in New Denominations'. Journal of the European Pentecostal Theological Association, 28 (2), 183-199

This Article is brought to you for free and open access by the Theology at Glyndŵr University Research Online. It has been accepted for inclusion in Theology by an authorized administrator of Glyndŵr University Research Online. For more information, please contact d.jepson@glyndwr.ac.uk. 


\title{
Sunderland's legacy in new denominations
}

\author{
Revd Dr. William K Kay \\ Reader in Practical Theology and Director of the Centre for Pentecostal and Charismatic \\ Studies, University of Wales, Bangor when article was written
}

Professor in Theology

Academic Leader for Humanities and Theology,

Glyndwr University, Wrexham when article published on this website
Pentecost at Sunderland: centenary conference on Pentecostal origins in Britain
St John's College, Durham
19-21 September 2007

address for correspondence:

Email: w.kay@glyndwr.ac.uk 


\section{Introduction}

In examining the contribution of the seven Sunderland conventions to the development of the Pentecostal movement in Britain, I make a number of assumptions. These assumptions are that the pentecostal movement begins in a state of disorganisation and, through a process of networking, conferences, emerging consensus and organisational initiatives, gradually turned into a series of discrete and separate denominations incorporating recognisably Pentecostal distinctives. The eventual variations between the denominations are partly doctrinal and partly administrative, and these differences depend upon factors that lie outside Sunderland. Sunderland is therefore important in the transitioning stage from the initial disorganised state to the eventual organised state.

In response to Alexander Boddy's invitation, T B Barratt came to Boddy's parish on Saturday the 31st of August 1907 and spoke the following day after the evening service to a small group in the vestry. The meeting continued into the early hours of Monday morning and there, on the premises of the Established Church, the first collective British speaking with tongues took place. In April 1908 Boddy published the first edition of Confidence and was able to say that more than 70 people had 'received a baptism of the Holy Ghost with the Seal of Tongues' (page 5) in Sunderland since September the previous year and that there were now altogether probably more than 500 people in Britain who had had the same experience. As he put it 'earnest pilgrims have come from all parts, and many have returned rejoicing and have been spreading the fire' (page 5). ${ }^{1}$ In the same issue Boddy was able to list 33 Pentecostal centres (32 excluding Sunderland) in Great Britain and Ireland. ${ }^{2}$ Each centre was accompanied by the name of a representative or correspondent.

It is impossible to believe that 32 different centres had sprung up directly as a consequence of contact with Sunderland, and Boddy never claimed that this was the case. Many of the centres were small and some had had a pre-existence as independent meetings with spiritual leanings which, in response to what was happening at Sunderland, took on Pentecostal characteristics. Confidence later explained how key members of these congregations had come to speak in tongues. Among those named in connection with the first tranche of Pentecostal centres was William Hutchinson of Bournemouth.

\section{Sunderland and Confidence}

It is convenient to consider the Sutherland conventions and the magazine Confidence together. Neither would have been as influential as it was without the support of the other. Alexander Boddy chaired all the conventions and edited all 141 issues of the magazine with the result that they were a coordinated expression of his ministry.

\section{Sunderland}

The first conference at Sunderland was held 6-11 June 1908. The format established there appears to have been maintained with minor variations until the last conference in 1914 . Essentially a theme was chosen and speakers were invited. There was worship where Pentecostal gifts were exercised and, in some or all of the conferences, chaired discussion was held in which various points of view were expressed. Many of the Sunderland sermons

\footnotetext{
${ }^{1}$ Confidence, September, 1908, 5, reported that Boddy had held 500 Pentecostal meetings in addition to regular parish work in Sunderland in the previous 12 months. About 100 people had received a definite baptism in the Spirit as a result.

${ }^{2}$ Centre is Boddy's word. Some were congregations, others prayer meetings and others seem to have been private houses where Pentecostal events occurred. The point is that the word has a general meaning.
} 
were reprinted in Confidence, as also were the discussions. It is therefore possible to gain an idea of the content of the ministry to which attenders were exposed as well as the range of opinion held by proto-Pentecostals.

In addition to the preaching and discussion, the Sunderland conference also issued a number of statements either by the International Advisory Pentecostal Council or by other gatherings. ${ }^{3}$ In this way the Sunderland convention also acted as an authoritative voice at a time when Pentecostalism was new, open to the derision of the secular media and to the more informed but still essentially prejudiced attacks of the religious press. Boddy was sensitive to the dangers of fanatical and wild behaviour and careful not to give the critics of incipient Pentecostalism grounds for their polemic. His status as an Anglican cleric undoubtedly helped to make Pentecostalism respectable - and respectability should not be seen as an entirely negative bourgeois concept in this context.

So when we come to examine the legacy of the Sunderland conventions within the Pentecostal denominations that were founded in the first part of the 20th century, we can anticipate examples of direct learning from Sunderland in terms of doctrine, experience and organisation. Sunderland, in other words, provided a template for later Pentecostal conferences and conventions and methods by which contentious issues might be addressed, acceptable doctrinal norms might be disseminated and a wealth of information communicated through testimony about experiences that could be regarded as safe, sane and free of the demonic. Yet, we can also postulate deliberate reaction against the stance of Sunderland as, for example, in the eventual rejection of Boddy's opinion that the Pentecostal outpouring ought to be contained within existing denominational structures rather than by the formation of new specifically Pentecostal groupings. ${ }^{4}$ In this sense Sunderland's legacy exists in two forms, the legacy of emulation and the legacy of reaction.

Having said this, it has to be admitted that it is difficult to disentangle with certainty the legacy of Sunderland from the legacy of other conferences and conventions. As a Boddy pointed out in June 1910,

when the first conference was held at Sunderland, Whitsuntide, 1908, there were no other conferences. Now there are many in Great Britain during the year. They have increased so much that we thought it possible there would not be the same large gathering here, but instead it has been larger, [with] more visitors from a distance, and, of course, more local attendances. The meetings at night were crowded out. We believe our parish hall holds about 700 when very full. ${ }^{5}$

The same preachers who attended Sunderland also travelled to other parts of Britain. For instance in 1909 T B Barratt recorded in his journal that he had attended a conference in London in May, the Sunderland conference in June and then, immediately after this, a

\footnotetext{
${ }^{3}$ Confidence, December, 1909, p.287, 288, also printed a firm declaration signed among others by Boddy, Polhill and Hutchinson, made in London, about the evidential value of tongues in connection with the 'Baptism in the Holy Ghost'. The International Advisory Pentecostal Council (originally called International Pentecostal Consultative Council) first met in Amsterdam in December 1912 and then in Sunderland in May 1913 and again in Sunderland in 1914. Barratt attended the first meeting but resigned over the Council's failure to make tongues the sign of the baptism in the Holy Ghost (see Wakefield, 2007, p142).

${ }^{4}$ As in the case of Assemblies of God, cited later.

${ }^{5}$ Confidence, June 1910, pp.127 and 128
} 
conference in Bournemouth. ${ }^{6}$ Similarly there was a conference in London for two days in January 1911 attended by about 500 people at which among others, Boddy, Cecil Polhill and Pastor Polman of the Netherlands spoke. ${ }^{7}$ Other conferences seem to have arranged their dates around the Whitsun holiday that Boddy had established as his own.

\section{Confidence}

The first edition of Confidence came out in April 1908 and was used to advertise the forthcoming convention. Boddy already had experience of circulating his tracts like the one that he had given out at Keswick and knew a little about printing and about circulating printed materials. ${ }^{8}$ The first edition of Confidence, like the tracts, was free though printing costs were notified to readers and donations implicitly solicited. The May 1908 issue stated 3,000 copies were printed and by January 1910 the print-run had risen to 4,000 and a year later this had gone up to between 5,000 and 6,000. Boddy estimated that they were roughly five readers for every issue printed so that his total readership amounted to nearly 30,000 , of whom some were overseas. ${ }^{9}$

In the first issue Boddy gave an explanation for launching the venture. Believers who had received the Pentecostal blessing were encouraged to discover that they were not alone even if they were 'attacked by doubt and difficulty' (page 3). For this reason the first edition contained reports from all over the United Kingdom where Pentecostal activities were in progress. A special supplement included a letter from T B Barratt giving an account of a heavily-criticised meeting that had taken place in Barmen, Germany, in December 1907. 'We cannot obtain any opportunity to reply in the columns [of the religious papers]' with the result that a new publication was needed. Barratt's tone is level and his comments factual but the entire episode demonstrates the swirling fear and uncertainty surrounding the appearance of Pentecostal phenomena.

Like the convention, the magazine also inspired copiers. Stanley Frodsham launched Victory in 1909; Fragments of Flame launched by Cecil Polhill gave missionary news between 1908 and 1925, Showers of Blessing, published by the Apostolic Faith group, lasted from 1910 to 1926 and Riches of Grace or to give it the Welsh name, Cyfoeth Y Gras was published by The Apostolic Church in Wales from April 1916 onwards. ${ }^{10}$ None of these magazines competed directly with Confidence. Some addressed the interests of emergent Pentecostal denominations while Polhill's was deliberately interdenominational and attempted to attract financial support for missionary work.

\section{British Pentecostal denominations}

Four British Pentecostal denominations emerged in the period before 1925. These were the Apostolic Faith Church (1911), ${ }^{11}$ The Apostolic Church (in Wales) (1916), the Elim

\footnotetext{
${ }^{6}$ Redemption Tidings 1st February, 1934, p.5

${ }^{7}$ Confidence, January 1911, p.3

${ }^{8}$ The first edition of Confidence gives a list of free Pentecostal publications available from the All Saints vicarage. The publications included a set of articles by T B Barratt as well as a series of testimonies and short pieces by Boddy himself.

${ }^{9}$ Confidence, January 1910, p.12.

${ }^{10}$ For details on Riches of Grace see Gordon Weeks (2003), Chapter Thirty-Two, Barnsley, Gordon Weeks, p.48. For the others see Wakefield, 2007, pp.107, 108.

${ }^{11}$ The building in Bournemouth opened in 1908 and was reported on in Confidence (November 1908, p.23, 24). It was named Emmanuel Mission Hall but it was not until afterwards that Emmanuel could be said to have linked up with other congregations in a quasi-denominational manner. Only in 1911 was Emmanuel renamed
} 
Pentecostal Church (1915) and the Assemblies of God in Great Britain and Northern Ireland (1924). ${ }^{12}$ Founding members of all of them attended the Sunderland conventions. We can deduce this from the names of those present and from the fact that in 1910 a group of 25 Welshman were present of whom some were from Penygroes. ${ }^{13}$ One way and another, therefore, all four denominations were influenced by Sunderland and what it stood for. ${ }^{14}$

\section{Hutchinson and the Apostolic Faith Church}

The story of William Oliver Hutchinson (1864-1928) is often omitted or reduced in accounts of British Pentecostalism because, though he started with great promise, he ended as an isolated figure adhering to doctrines that the vast majority Pentecostals rejected. Yet to Hutchinson goes the honour of erecting the first purpose-built Pentecostal building in Britain. He left the Baptist Church, acquired land and built Emmanuel Mission Hall. This was opened on $5^{\text {th }}$ November $1908 .^{15}$ Less than two years later he founded Shower of Blessing which may have had a circulation of about 10,000 copies per year. ${ }^{16}$

In the period between 1908 and about 1912 Hutchinson was an invited speaker at several international conventions and, from the coverage given to him by Confidence, it would appear that his preaching and doctrine were entirely acceptable to the majority of Pentecostal sympathisers. Hutchinson made an impact on the mini-revival in the Kilsyth area to which Boddy, in March 1908, had been an 'overwhelmed' visitor. ${ }^{17}$ No less a person than Cecil Polhill, evangelical Anglican to his bones, spoke at the opening of the Bournemouth church later that year. In 1909, T B Barratt treated the Bournemouth convention as one worthy of his time and preaching. Hutchinson was a signatory to the London statement on baptism in the Spirit in $1909^{18}$ and his travelling ministry enabled him to link up with proto-Pentecostal assemblies in south Wales that had vivid memories of the revival and still retained revivalistic features. As we have seen Hutchinson attended Sunderland in 1908. In 1910 he

Apostolic Faith Assembly and then later that year Apostolic Faith Church. Incidentally, J E Worsfold (1991) The Origins of the Apostolic Church in Great Britain, p.31, puts the date for the opening of Emmanuel Mission Hall at 1909 but this must be incorrect.

${ }^{12}$ Assemblies of God changed its name and is now Assemblies of God in Great Britain and Ireland. The Elim Pentecostal Church also changed its name on more than one occasion. Similarly The Apostolic Church (in Wales) is also sometimes delimited by a geographical restriction. The names are relatively unimportant because there is continuity between the earlier and later groups of churches to which the changed names are attached.

${ }^{13}$ Confidence June 1910, 125. Reference to Penygroes, where the Williams brothers were, is given on page 131.

${ }^{14}$ In what follows, reference is made to the main leaders of the new British Pentecostal denominations. But it is also true that a host of minor figures also attended included James Tetchner, J Reginald Knight who was an Elim minister from 1927 and E J Phillips. I am grateful to Desmond Cartwright for this information. Smith Wigglesworth also attended Sunderland and received his Spirit-baptism there in 1907 at the hands of Mary Boddy. He can hardly be called a minor figure, but he was not associated in any formal way with the Pentecostal denominations. D N Hudson (2001), 'The earliest days of Pentecostalism', Journal of the European Pentecostal Theological Association, 21, 49-67, points out that there were also group of other Sunderlandattending leaders like the Walshaws from Halifax and Henry Mogridge from Lytham, Lancashire, who led prayer groups or growing meetings that later became Pentecostal assemblies of one kind or another.

${ }^{15}$ Kent White (1919), The Word of God Coming Again, Bournemouth, p.51.

${ }^{16}$ Since Confidence peaked at about 6,000 copies per issue, I find Worsfold's figure of 10,000 improbable. Perhaps Hutchinson claimed a readership of 10,000, which would put his circulation at about 2,000 copies, a much less expensive print-run.

${ }^{17}$ Confidence April 1908, p.8

${ }^{18}$ Confidence December 1909, p.287. 
attended again but this time as an invited guest to share in the preaching on the topic of divine healing. Boddy thought his sermon 'wonderful'. ${ }^{19}$

Hutchinson's position began to fall apart as far as other Pentecostals were concerned after 1910. He began to believe that the 'spoken word' by which he meant prophecies or interpretations of utterances in tongues should be treated as if they were canonical Scripture and that any disobedience to such utterances should be treated as disobedience to God. Prophecies, in Hutchinson's opinion, should not be judged - thereby contradicting the specific New Testament injunction of 1 Corinthians 14.29. Speaking two years later Hutchinson was to say "we passed through great testings on believing the "Spoken Word"" 20 A year later Hutchinson began to make a doctrine of the practice of 'pleading the blood'. This practice entailed either speaking the word 'blood' rapidly and frequently or else in prayer calling the word out. The practice was equated with the Old Testament notion of sprinkling blood upon the altar to sanctify it. In the New Testament dispensation pleading the blood was seen as an ultimate defence mechanism to prevent any demonic interference in the mind and life of the individual. So, to plead the blood, produced a form of inviolability that, at the same time, guaranteed the free and pure operation of the Holy Spirit. The two practices, treating interpretation/prophecy as infallible and pleading the blood, reinforced each other since the second guaranteed the first. About two years later in 1912 Hutchinson was appointed as the first apostle of his church in response to direction given by spiritual gifts. $^{21}$ Once installed into apostolic office, he was raised beyond criticism to a place where he was incapable of error. At a conference in Bournemouth in 1914 Showers of Blessing reported on preaching and prophecy and then 'almost all the congregation came forward and laid their all at the apostle's feet, Pastor W Hutchinson, God's anointed apostle. Men, women and even children reverently kneeled down, some brought their jewellery, others money...,22

After this, in 1916, the Welsh churches seceded. ${ }^{23}$ By 1917 Hutchinson was preaching about the man-child in the book of Revelation and claiming the term denoted a special group called out of the church, an overcoming company of the elect destined to be raptured before the anti-Christ inaugurated the great tribulation. ${ }^{24}$ Alongside this doctrine Hutchinson embraced British-Israelism declaring that Daniel's fifth kingdom was the British Empire and that George V was the king of Israel. ${ }^{25}$ After other defections, Hutchinson died in 1928.

\section{Sunderland and Hutchinson}

Hutchinson's attendance at Sunderland in 1908 would have led him to hear a variety of messages and, probably, to read the issue of Confidence that recounted the details of conference sessions. He would have heard Boddy saying that 'speaking from Scripture, we

\footnotetext{
${ }^{19}$ Confidence June 1910, p.138

${ }^{20}$ Hathaway, 1996. Worsfold (1991, p.121) quotes Hutchinson's son-in-law 'now to deal with the difference between the written and spoken word. Going straight to the root of the matter there is no difference at all, because if it is the Word of God - whether written or spoken - it cannot be anything else but God's Word and therefore in that sense the same, identically'.

${ }^{21}$ Worsfold, p.121 says "Hutchinson even used the word "infallible" when it came to describing the nature of the ministry of the voice Gifts' (original capitalisation).

${ }^{22}$ Worsfold, p.87.

${ }^{23}$ A full account of the marathon meeting and the walk-out is given by Weeks (2003, p.45).

${ }^{24}$ Hathaway, 1996. See also Worsfold, p.149.

${ }^{25}$ Hathaway, 1996.
} 
see no warrant for expecting a message in tongues for details of daily life and guidance' ${ }^{26}$ He would have gathered that 'probably all the Nine Gifts have been in evidence during the conference' a statement suggesting that the gifts had already been enumerated by counting from 1 Corinthians $12 .^{27}$ He would have heard a discussion on prophetic messages brought before the conference by Boddy himself. Here he would gather that 'even earnest Baptised ones had unconsciously spoken "in the flesh" " and that "there was no scriptural authority or precedent for making tongues (with interpretation) into a Urim and Thummim Oracle for details of daily life'. Within the discussion one of the ladies present, Miss Schofield, pointed out that 'I find it a great help to recognise the influence of the unconscious mind', which might lead to erroneous prophetic utterance. According to Miss Scott, 'there is a subtle danger of continuing in the flesh after a message is being given in the Spirit' and that some of the Apostolic Faith Missionaries from Azusa Street who went out to Africa died. And this despite the fact that they had been apparently called 'by the Spirit'. ${ }^{28}$ On the same day there was discussion of the return of Christ and a Miss Sisson stated that 'the Dragon is longing to swallow up the Man-child... [with the result that] the Warrior-spirit is necessary'. ${ }^{29}$ In the final act of the conference testimonies given in the morning included one by a leader (Pastor Jeffreys of Waunlwyd) in South Wales against following human leaders. Like others in Wales he had mistakenly accepted 'the teaching of one who had caused many to turn from God's best in these days'. ${ }^{30}$

Taken together these discussions appear to have largely fallen on Hutchinson's deaf ears. He seems to have been impervious to any doubt about prophetic utterance or of the trivialising of such messages in respect of commands for daily life. The discussion of the man-child seems to have lodged in his brain but to have issued in an elitist doctrine that was disastrously schismatic.

It is therefore possible to argue that the 1908 conference had little beneficial effect on Hutchinson and that its warnings and hesitations were brushed aside. It is also possible to speculate that behind the doctrine of the man-child or the doctrine of British-Israelism lay Charles Fox Parham's book, A Voice Crying in the Wilderness, which gave credence to both these topics. The book was published in 1910 and known in Pentecostal circles. We can hardly blame Boddy for failing to mount a critique of Parham's writings since they must have been only occasionally and superficially known in Britain but, if Hutchinson had assimilated them, then we have identified one source of his subsequent spiritual opinions.

The 1910 conference centred on divine healing and Hutchinson himself contributed to the preaching. There was a message by Mary Boddy on Isaiah 53.4 emphasising healing in the atonement and there was a memorial service commemorating the burial, on that day, of Edward VII. What we can say is that Hutchinson's strong views, on healing and on the role of Britain in the world, would hardly have been challenged by what he heard or by the favourable reception given to his own preaching. In short, the legacy of Sunderland to the ministry of Hutchinson is one of reaction. He rejected the critical, careful, balancing elements of the conferences and instead took hold of other less well defined and submerged elements, the dark side of Pentecost.

\footnotetext{
${ }^{26}$ Confidence June 1908, p.13. Original italics.

${ }^{27}$ Confidence June 1908, p.15. Original capitalisation.

${ }^{28}$ Confidence June 1908, pp.15, 16

${ }^{29}$ Confidence June 1908, p.17.

${ }^{30}$ Who was Jeffreys thinking of? My guess is that he is referring to Jessie Penn-Lewis.
} 


\section{George Jeffreys and Elim}

The relation between the Jeffreys Brothers, George and Stephen, and the Sunderland conventions is altogether more positive. George Jeffreys was converted during the Welsh revival of 1904 and baptised in the Spirit with speaking in other tongues in 1910. There are questions about whether he received his baptism in the Spirit at the hands of William Hutchinson in Bournemouth or in south Wales. ${ }^{31}$ If the latter, then Jeffreys took steps in later life to protect himself from guilt by association with the bizarre theological positions adopted by Hutchinson. In 1912 George Jeffreys was offered a free place at the Pentecostal Missionary Union's (PMU) school run by Thomas Meyerscough thanks to the generosity of Cecil Polhill. ${ }^{32}$ The two brothers, referred to in Confidence as 'the Welsh revivalists', 33 preached wherever they were invited to go and undeniably stirred the embers of revival in South Wales. Unannounced Boddy went to see them in March 1913 and, after observing them in action, invited them to speak at Sunderland. Confidence regularly thereafter reported the progress of the brothers so we can trace their steps to Llanelli, Plymouth, Ireland, Hereford, London and Belfast. ${ }^{34}$

The themes of the 1913 Convention were 'the task of the Pentecostal movement' and 'the conditions of an apostolic revival'. In a sense of Boddy appears to have already decided the answer to these questions and arranged the preaching schedule accordingly. So he reports the task of the Pentecostal movement has been to "stir up the people of God for the edification of the body of Christ... restoring apostolic gifts... [and] preaching the gospel to the world as a last call of the Lord'. He took the apostolic revival as being fired by meetings that were led by the Holy Ghost and forwarded by preaching in the demonstration of the Spirit and power'. ${ }^{35}$

\section{Sunderland and the Jeffreys Brothers}

The Sunderland conventions appear to have had an entirely beneficial impact upon the Jeffreys brothers. ${ }^{36}$ They introduced the two young men to a much wider circle of Christians than they were accustomed to and helped them understand the role of the Pentecostal movement in relation to the rest of the church and, by extension, the rest of the world. By public affirmation, their preaching and beliefs in healing and tongues were confirmed and, in passing, they learnt the importance of national publicity in the print media. The 1913 convention also had a valuable consequence of issuing a rebuttal of Mrs Penn-Lewis' book, War on the Saints. ${ }^{37}$ The book was effectively a repudiation of Pentecostal phenomena in the Welsh revival as well as a fear-driven tract about deceiving spirits in the last days. The handling of this rebuttal was dignified and logical and did not go out of the way to provoke

\footnotetext{
${ }^{31}$ Discussed fully in D N Hudson (1999), A Schism and its Aftermath: an historical analysis of denominational discerption in the Elim Pentecostal Church, 1939-1940, King's College, London, unpublished PhD thesis.

${ }^{32}$ Confidence October 1913, p.205.

${ }^{33}$ Confidence March 1913, p.47. They joined forces with Dan Roberts, the brother of Evan, at one point.

${ }^{34}$ Confidence May 1914, April 1915, May 1915, August 1915, October 1915, November 1915, January 1916, and frequently thereafter.

${ }^{35}$ Confidence April 1913, p.74.

${ }^{36}$ Although they were both invited, only George is mentioned as preaching at the 1913 convention. Stephen did, however, join George for a mission in Silksworth near Sunderland once the convention ended, Confidence December 1913, p.244.

${ }^{37}$ Confidence June 1913, p.111. The statement was issued by the International Advisory Council (Pentecostal).
} 
contention, something that both brothers appreciated. ${ }^{38}$ Perhaps the only unforeseen negative consequence of the conventions was that John Leech, later a strong advocate of BritishIsraelism and influential on Jeffreys, spoke at Sunderland and, if the two men had not met before, George would have had heard him there. At the time Leech offered an innocuous sermon expounding aspects of kenotic Christology.

\section{John Nelson Parr, the Carter brothers and Assemblies of God}

British Assemblies of God came into existence as a result of the coordination of apparently disconnected events organised by different people. The most important agent was John Nelson Parr who convened a gathering of some 15 people in Birmingham in $1923 .{ }^{39}$ Both he and the other protagonists in these events - particularly Donald Gee and the Carter brothers left behind their own accounts of the formation of Assemblies of God and the preceding events. Yet, the best version by far is to be found in Richard Massey's A Sound And Scriptural Union (1987) which rationally harmonises the various accounts and explains contradictions, omissions and variations. To a large extent, this paper will follow Massey, though in the era preceding 1914 will draw on other sources as well.

\section{In 1974 John Carter recalled,}

Right up to the time of the formation of this Fellowship in 1924, God had been pouring out his Holy Spirit in this country for 17 years, and many Pentecostal congregations had come into existence, mainly through eager believers visiting the annual conventions at Sunderland. Up to this point there was no organised fellowship, each group being quite independent, except for those who had linked up with the Elim church or the Apostolic Church. These unattached groups of believers had no wish to become affiliated with the centrally-governed bodies having in many instances suffered from denominational connections because of their Pentecostal experience. They supported their own local conventions as well as the national conventions held in Kingsway Hall, London, and at Preston and Bradford. The one connecting medium was the quarterly magazine entitled Confidence published by the Church of England vicar at Monkwearmouth, Sunderland. ${ }^{40}$

In the same sermon John recalled the Pentecostal Missionary Union (PMU) of 1909 and the Bible School at Hampstead for training Pentecostal missionaries. By 1920, his brother Howard had been appointed its principal. At this time there were therefore the two main organised Pentecostal bodies (Elim and the Apostolic Church) and an interdenominational missionary society with a feeder training school supported by diverse independent Pentecostal assemblies. Both Carters had attended Sunderland in 1912 and a year later, as a result of seeing report in Confidence, participated in the launching of a small Pentecostal

\footnotetext{
${ }^{38}$ In their various ways the brothers later became embroiled in controversies, Stephen with the scurrilous Horatio Bottomley and George with the rest of Elim. As much as possible, the brothers kept the lid on controversy. Or take Boddy's comment 'There has been renewed opposition of late in England against the truth and experience of the Pentecostal Baptism. The Editor of "Confidence" does not feel that bitterness should be met by bitterness. He regrets the lack of generosity and chivalry in some of the things recently written' (Confidence September 1912, p.202).

${ }^{39}$ Massey, 1987, p.92 discusses the conflicting evidence about who was present and settles on 15 people, among them Harold Roe, who provided the room in Aston where they met.

${ }^{40}$ The sermon is simply entitled 'Given at the Jubilee Rally, Birm.' and is kept at the Donald Gee Centre, Mattersey, Carter was born in 1893 and so aged about 80 at the time he preached at the rally, 50 years after AoG's founding.
} 
mission in a suburb of Birmingham. ${ }^{41}$ They began a second assembly in another part of the city in $1915 .^{42}$ Meanwhile they continued visits to Sunderland, also attending in 1913 and $1914 .^{43}$

The Hampstead School of which Howard Carter became principal had started under the auspices of Thomas Myerscough. In Myerscough's days both W P F Burton and George Jeffreys had been students - as good an advertisement for Bible college training as one is likely to get! ${ }^{44}$ Myserscough was associated with the Preston assembly from which the young Burton had left England for his heroic labours in the Congo in 1914. ${ }^{45}$ In 1922 Burton, while on furlough, had attempted to call the various Pentecostal assemblies together so as to coordinate missionary support. Burton's name heads a broadsheet listing those who called a two-day conference in Sheffield, May 23-24 1922, and George Jeffreys' name is also prominently displayed. But Sheffield envisaged a 'council of leaders rather than a confederation of assemblies ${ }^{46}$ with the result that the proposal fell to the ground. In 1923 Archie Cooper of South Africa, who knew Burton, itinerated the British assemblies on a preaching tour but also took the opportunity (probably instigated by Myerscough who in turn was responding to Burton) to sound them out on a new collaborative scheme. Myerscough, as Massey points out, appreciated Nelson Parr's gifts and so encouraged him to build on the encouraging responses to Cooper's enquiries. ${ }^{47}$

Parr proceeded slowly, first by getting the agreement of Myerscough and others, and afterwards by calling together a representative group of leaders who met over a garage in Birmingham in 1924. This meeting then approached about 80 congregations and a second meeting was held at Highbury in London the same year. The deliberations of the two meetings resulted in agreement to form an organisation that safeguarded the autonomy of local congregations because 'at that time we were fanatically opposed to any form of denominationalism'. ${ }^{48}$ Parr's reasons for drawing together Assemblies of God were fivefold: to preserve the testimony of the full gospel; to strengthen fellowship; to exercise discipline over immoral believers; to present a united witness; and to save assemblies from falling into unscriptural practices. ${ }^{49}$ Massey focuses on three reasons: the harsh treatment meted out to Pentecostal pastors who became conscientious objectors during the 1914-18 war; the havoc created by teachers of universalism; and divisions caused by the wrong use of prophetic gifts. $^{50}$ By 'wrong use' they had in mind the teachings of the Apostolic Church which was

\footnotetext{
${ }^{41}$ John Carter (1979) A Full Life, London, Evangel Press, p.30, 31 'Things happened in our lives as a result of us attending the 1912 Pentecostal Convention at Sunderland'.

42 John Carter (1979) A Full Life, London, Evangel Press, p.32.

${ }^{43}$ John Carter (1971), Howard Carter: man of the Spirit, Nottingham, Assemblies of God, p 21.

${ }^{44}$ Confidence October 1913, p.205 and Harold Womersley (1973), Wm F P Burton: Congo pioneer, Eastbourne, Victory Press, p.29.

${ }^{45}$ Womersley (1973) Wm F P Burton, p.32. Confidence August 1911, p.190. There is reference to Burton speaking at a Pentecostal conference in London in January 1912. See Confidence in February 1912, p.36.

${ }^{46}$ Richard D Massey (1987), 'A Sound and Scriptural Union': an examination of the origins of the Assemblies of God in Great Britain and Ireland during the years 1920-1925, University of Birmingham, PhD unpublished dissertation, p.50.

${ }^{47}$ Massey, 1987, p.69.

${ }^{48}$ See a typescript of a conversation between the Carter brothers entitled Those Early Days, p.1. The typescript is kept at the Donald Gee Centre, Mattersey, and the conversation took place in the early 1970s. Howard is speaking.

49 These reasons are given in Parr's letter of invitation to the leaders who met at Aston in 1924.

${ }^{50}$ Massey, 1987, p.76.
} 
still under the influence of Hutchinson. Parr took the model for his constitution from American Assemblies of God although he does not anywhere appear to have acknowledged this in print. Massey's case, however, is overwhelming. The year after British Assemblies of God had been formed the Pentecostal Missionary Union (PMU) amalgamated with the new denomination with the result that the aims of Burton (and Cooper) had been achieved. As for British Assemblies of God, it found itself at a stroke armed with an overseas dimension.

\section{Sunderland and Assemblies of God}

Although British Assemblies of God was formed 10 years after the last Sunderland convention, Sunderland bequeathed at least five positive components to what became, until the early $21^{\text {st }}$ century, the largest Pentecostal denomination in Britain. First and most general, was the notion of making decisions as result of a lengthy and open deliberation. Sunderland did not include any system for voting, as the Assemblies of God until very recently always did, ${ }^{51}$ but the notion of a conference with its chairman and the delegates who discussed propositions was carried over into the Assemblies of God in a way that is much more difficult to believe would have been the case had the example of Sunderland not been set. It is true that both Elim and the Apostolics also held conventions that were chaired in a similar way but, Assemblies of God particularly, was almost to a fault driven for more than 70 years by the debating of propositions.

Second, the position taken on speaking in tongues as initial evidence of Spirit-baptism could have been derived from Sunderland even if, eventually, the Sunderland position on the role of evidentiary tongues was softened. Nevertheless, by the time when the Carter brothers attended Sunderland, at least two statements about the role of tongues had been published in Confidence and, indeed, it is arguable that Boddy's own position on the matter was not modified to deny his earlier stance (tongues as a 'seal' of Spirit-baptism). ${ }^{52}$ In this connection Parr's autobiography gives Sunderland an honoured place in the initiation of the Pentecostal revival as well as stressing the role of tongues.

The Rev A. A. Boddy planned a great Whitsuntide Convention at All Saints, Sunderland, and the chief speaker was Rev. T. B. Barrett (sic). We decided to send brother Dan Parsley to this convention and bring back a report. He came back and told us that it was just like the Acts of the Apostles. Jesus was gloriously magnified, many were speaking other tongues. Many miracles of healing were seen in the name of Jesus... we became very desperate and we decided to hold a Christmas Convention... we invited two or three from Kilsyth and Preston who had been Baptised in the Spirit and spoken in tongues. Many people had been to Sunderland and the Pentecostal revival had spread to Preston, Lytham, Kilsyth, Blackburn, London and other places. ${ }^{53}$

Third, the eschatology of Sunderland was a fundamental to its main thrust and development. It was the time of the bridal call, the midnight hour, the last birth pangs of the age before the return of Christ. There was no disguising the Adventist fervour within Sunderland's ranks and such fervour was shared by and transferred to the infant British Assemblies of God.

\footnotetext{
${ }^{51}$ Voting was removed progressively during the 1990s and more or less completely dispensed with by 2007.

${ }^{52}$ E.g. Confidence December 1909, p.287 and Confidence April 1908, p.5.

${ }^{53}$ J N Parr (1972), Incredible, Fleetwood, self-published, p 22.
} 
Fourth, a belief in healing - healing in the atonement - was also to be found in Assemblies of God. This was a position that Nelson Parr had reached and, again, it is possible that there were other influences outside Sunderland that converged on this belief. Some of the Parr's writings suggest that he had read Parham, for instance. ${ }^{54}$ Nevertheless, despite Boddy's own more nuanced position, his wife's teaching was always almost uncomplicatedly in favour of a divine healing doctrine. ${ }^{55}$

Fifth, as John Carter's recollections show, he and his brother participated in the formation of an early Pentecostal mission because of what they read in Confidence. This points to the publicising impact of Confidence in its capacity to help proto-Pentecostals find each other and work together. ${ }^{56}$ Boddy may have foreseen that Confidence would encourage little Pentecostal groups but he may not have anticipated that the Pentecostal groups themselves would grow larger as a result of the publicity that his listings would give them. And, in the case of John Carter, he joined the early Elim Evangelistic Band and worked with George Jeffreys in Ireland for a while. Given that Confidence supported Jeffreys, Carter must, in those early days, have felt safe in joining the new Pentecostal enterprise. In this sense Boddy acted as a kind of one-man vetting agency whose quality mark was trusted.

Insofar as Assemblies of God illustrated a reaction against Sunderland, it is clear that the formation of another Pentecostal group was, in itself, not something that Boddy would have smiled upon: "The Editor of "Confidence" does not feel that the Lord's leading in these days is to set up a new Church, but to bless individuals where they are'. ${ }^{57}$ This said, it is also true that T B Barratt, whom Boddy respected deeply, took the opposite position. Barratt believed that in view of the rejection of Pentecostalism by the established churches, there was no option before Pentecostal believers than to found their own denominations, as he himself had done in Norway. Barratt's position was not sectarian. As he wrote in 1926

I am willing to have an Alliance with any of God's people, and cooperate with them, even if their views are not correct in some matters, according to the light God has given me...I found it right to found a Pentecostal Church in Oslo. We have over 1000 baptized members now, and crowds attend our services. ${ }^{58}$

Finally, we know that Boddy did not take a pacifist position which, when Parr wrote the original constitutional minutes of Assemblies of God, he was careful to do. So far as we can see this was entirely Parr's initiative even if both the Carter brothers and Donald Gee had been conscientious objectors.

\section{Conclusion}

\footnotetext{
${ }^{54}$ In their visceral rejection of medical science both refer to the connection between the Greek word for medicine (pharmakia) and sorcery. See Charles F Parham (1910), A Voice Crying in the Wilderness $\left(4^{\text {th }}\right.$ edn 1944), Baxter Springs, Kansas, p.41, and J N Parr (1955) Divine Healing, Springfield, Gospel Publishing House.

${ }^{55}$ Cf Boddy's position in Confidence Mark 1910, pp.175-179 and Mary Boddy's views on Isa. liii., 4 : 'SURELY He hath borne our sicknesses and carried our pains.' (Confidence June 19110, p.132. original capitalisation).

${ }^{56}$ To complete the Assemblies of God picture it is necessary also to add the name of E W Moser, treasurer of the PMU, who was also linked with Sunderland since it was in the All Saints Vicarage at Sunderland that the Union had been founded. Moser was present at the inaugural meeting in Aston where Assemblies of God was born.

${ }^{57}$ Confidence March 1911, p.60.

${ }^{58}$ T B Barratt letter to E J Phillips dated $17^{\text {th }}$ August 1926 and held in the Donald Gee Centre, Mattersey.
} 
Of the conclusions that might be drawn, we present four here.

1. The founding members of Pentecostal denominations recalled the Sunderland meetings with affection. Representatives of all the denominations had attended one of the conventions. In their own accounts of the beginnings of British Pentecostalism, they were quick to pay tribute to the spiritual banner that had been raised in Sunderland by Alexander Boddy. Naturally, as the years passed, the influence of Sunderland receded but, conversely, during the time of its greatest influence, spin-off conventions and publications reflecting with greater or less accuracy its ethos and emphases multiplied and diffused its effect. For the seven crucial years preceding the catastrophic events of World War I, Sunderland shaped British Pentecostalism and exercised a profound influence.

2. Sunderland was concerned with missions and supported the Pentecostal Missionary Union. This is partly because Boddy very rapidly appreciated the international dimension of the Pentecostal outpouring. He corresponded with preachers from overseas and invited them to speak at the convention. He reported on revivals and Pentecostal events in different parts of the world and sent out Confidence to many countries of the world. Anyone associated with Sunderland quickly came to appreciate that they were involved with a major spiritual event. They also were led to understand that missions needed to be funded and that major international events could be fitted into pre-millennialist eschatological schemes.

3. Sunderland's contribution to the doctrinal formation of Pentecostalism was extensive. There were, it is true, those like Hutchinson who heard its message and went off in their own direction. But the majority of visitors appreciated the balance and general rationality of what was presented to them. This was Pentecostalism without scandal or dissension engendered by heterodoxy. While early Pentecostalism in the United States was damaged by a form of Unitarianism, British Pentecostalism escaped these pains and, when the infamous Berlin Declaration of 1909 was issued in Germany, Boddy was able to offer advice and support to his German brothers. Indeed, it ought to be possible to make a similar examination to the one presented here of Sunderland's impact both on German and Dutch Pentecostalism.

4. Paths crossed in Sunderland and there must have been considerable networking among conference attendees. The British Pentecostals knew each other personally and came quickly to have defensible opinions on contentious issues like those concerning the use of prophecy. While it is true that Hutchinson and the Apostolic Church took a different position from the majority of British Pentecostals, it is also true that the Apostolic Church in Wales reined in the effects of prophecy by drawing up a powerful constitution that created an environment in which prophets were required to work. In this way there was a check on the ministry of New Testament prophets and, eventually, the Apostolic Church and the two other British Pentecostal denominations, Elim and the Assemblies of God, were able to resume fraternal relations, as the Unity Conference of 1939 demonstrates. 